\title{
Gender and sports studies: an historical perspective ${ }^{\star}$
}

\author{
Susan J. Bandy \\ College of Education and Human Ecology, Department of Kinesiology, Ohio State University, Columbus, Ohio (USA)
}

Received 5 February 2013 - Accepted 27 October 2013

\begin{abstract}
In the late 1970s, scholars from North America began to incorporate gender in their critique of contemporary sport, and soon thereafter European sports scholars also embraced gender as a transformative concept in the discipline of Sports Studies. Initially, scholars focused on the female athlete as a subject from a disciplinary perspective. With the inclusion of gender in the 1980s, scholars turned from a "categoric" to a "relational" perspective and gender was thus expanded beyond that of a distinct category and redefined as a dynamic, relational process that introduced new directions, theories, and paradigms for research in Sports Studies as the focus shifted from the female athlete to a cultural critique of sport using interdisciplinary and cultural studies perspectives. Most recently gender has been viewed as both interrelational and intersubjective as scholars began to challenge the universalizing nature of feminism and its uniformity in the 1990s. A paradigmatic shift toward intersectionality emerged and enabled scholars to critique the view that gender was monolithic; rather they purported that it intersects with a number of other dimensions of human experience and identity such as age, ethnicity, race, and social class in sport. This shift encouraged a more trandisciplinary and transnational focus concerning the study of sport. This perspective has paralleled and contributed to the inclusion of such topics as language, power, narrativity, and representation and has yet again transformed the scholarly analysis of sport.
\end{abstract}

Key words: Gender, sport, history, trandisciplinarity, intersectionality

\section{Résumé. Sport et Genre : une perspective historique.}

À la fin des années 1970, les chercheurs d'Amérique du Nord ont commencé à intégrer la notion de genre dans leur critique du sport contemporain. Peu de temps après, les Européens ont également adopté le genre comme concept pour étudier les transformations du sport. Dans un premier temps, les chercheurs se sont concentrés sur l'étude des femmes athlètes en menant des travaux disciplinaires. À l'issue de l'introduction du concept de genre dans les années 1980, les chercheurs ont fait évoluer le statut de ce concept, d'abord appréhendé en tant que catégorie sociale, pour l'appréhender d'une manière plus large en étudiant les rapports sociaux de sexe. La signification du concept de genre fut donc étendue et redéfinie comme l'étude des rapports sociaux de sexe, permettant ainsi d'envisager de nouvelles directions et d'introduire de nouvelles théories et paradigmes dans les recherches. Les objets d'étude se sont alors déplacés. Après s'être concentrés sur l'évolution du sport feminin, les travaux se sont progressivement inscrits dans une histoire culturelle et des perspectives interdisciplinaires. Plus récemment, le genre a été vu à la fois comme analyseur interrelationnel et intersubjectif par l'intermédiaire de travaux visant à contester le caractère généralisant du féminisme et de son uniformité dans les années 1990. Un changement paradigmatique vers l'intersectionnalité a émergé et permis aux historiens du sport de critiquer la vision monolithique du genre en introduisant de nouvelles dimensions de l'expérience humaine et de l'identité tels que l'âge, l'ethnicité, la race et la classe sociale. Cette évolution s'explique aussi grâce à l'introduction de nouveaux objets tels que la langue, la puissance, la narrativité et la représentation, permettant ainsi d'enrichir l'analyse savante du sport.

Mots clés : Genre, sport, l'histoire, trandisciplinarity, intersectionnalité

\footnotetext{
${ }^{\star}$ A version of this paper was previously as a chapter published in S. Pope \& J. Nauright. (2010). Routledge Companion to Sports History. New York: Routledge Taylor and Francis Group.
} 


\section{Introduction}

In 1978, Canadian sport sociologist Ann Hall formally introduced the concept of "gender" in sport studies" in a monograph entitled Sport and Gender: A Feminist Perspective on the Sociology of Sport in which she reviewed the sociological research and literature as it related to the female experience in sport and offered a critique of this material from a feminist perspective. Hall's use of the term "gender" was, to the best of my knowledge, without precedent in sports studies, and, in retrospect, her early work seems crucial to the development of sports studies because it brought the concept into the discourse and called for a feminist perspective, which would begin to significantly alter research in sport studies. With the work of Hall and others, who began to use the concept "gender" rather than "sex". Gender was used to reject biological determinism and to view the behavioral, cultural, or psychological traits typically associated with one sex as socially constructed. The focus of research began to shift away from the female athlete toward the concept of "gender" and later to a critique of sport and physical culture, as I have argued elsewhere (Bandy, 2004a) ${ }^{2}$. As I will attempt to show in this paper, the concept of "gender" would be further expanded beyond that of a distinct category and redefined as a dynamic, relational process that introduced new directions, theories, and paradigms for research in the discipline of sports studies. Moreover, the inclusion of the concept of "gender" - along with such concepts as race, social class, and ethnicity, as well as a turn toward postmodernism and deconstruction (and the introduction of theories of hegemony and power) - further encouraged the study of such topics as globalization, post-colonialism, space, and the media that moved the development of the discipline of sports studies from a disciplinary to an interdisciplinary focus. Most recently "gender" seems to have been viewed as an interrelational concept by scholars, and this perspective has paralleled and contributed to the inclusion of such concepts and topics as language, narrativity, power, and representation with a more recent transdisciplinary and transnational focus in the study of sport (Bandy, 2004b, pp. 17-39). A "cultural turn" in many disciplines at this time spawned a focus on cultural anthropology, cultural history, and cultural sociology as well as the creation of new fields of study including Cultural Studies and African American Studies.

The essay begins with an examination of scholarship in North America and Great Britain and shows the origin of the study of gender and sport and notes that this

\footnotetext{
${ }^{1} \mathrm{I}$ am using the term sports studies to include the various names that are and have been used by departments that are devoted to the study of sport and physical culture. Among the more common of these are: exercise science, idrat, human movement studies, kinesiology, physical education, and sport science.

2 For a more detailed analysis of this transition from "sex" to "gender" see Birrell (1988) and Hall (1988).
}

scholarship includes the largest volume, the most varied examples and interpretation of the subject, and the fullest elaboration of the theoretical debates concerning gender and sport ${ }^{3}$. It includes as well the subsequent work done by European scholars in sports studies.

\footnotetext{
3 Considerable work concerning gender and sport has been done by scholars in a number of other countries. For example, see Trangbæk and Krüger (1999); Pfister (2000), pp. 170-201; and Hartmann and Pfister (2003). Also for international perspectives, see the following:
}

Argentina: Liana Morelli. Mujeres Deportistas (Buenos Aires: El Planeta, 1990). Australia: John Daly. Feminae Ludens (Adelaide: Openbook Publishers, 1994). Canada: Jean Cochrane, et al. Women in Canadian Sports (Toronto: Fitzhenry and Whiteside, 1977); M. Ann Hall and Dorothy Richardson. Fair Ball: Towards Sex Equality in Canadian Sport (Ottawa, ON: The Canadian Advisory Council on the Status of Women, 1982); Laura Robinson. She Shouts She Scores: Canadian Perspectives on Women and Sport (Toronto: Thompson Educational Publishers, 1997); and Phillip White and Kevin Young, Eds. Sport and Gender in Canada (Oxford: Oxford University Press, 1999); M. Ann Hall, The Girl and the Game: A History of Women's Sport in Canada (Peterborough, Ont.: Broadview Press, 2002); China: Fan Hong. Footbinding, Feminism and Freedom: The Liberation of Women's Bodies in Modern China (London: Frank Cass, 1997) and Jinxia Dong. Women, Sport and Society in Modern China: Holding Up More than Half the Sky (London: Frank Cass, 2003). Denmark: Inge Kryger Pedersen. Den excellente prastation. Elitesport, kvinder og Karriere (Sociologisk Institut, Københavns Universitet, 1998); Thing, Lone Friis. Sport - en emotional affäre. Kvinder, holdsport og aggression (Sociologisk Institut, Københavns Universitet, 1999); and Alice Riis Bach. Kvinder på banen: sport, køn og medier (København: Narayana Press, 2002). France: Françoise Laget, et al. Le Grand Livre du Sport (Bellville-s-Saone: SIGEFA, 1982) and Pierre Arnaud and Theirry Terret. Histoire du sport féminin (Paris: L'Harmattan, 1996). Germany: Gertrud Pfister. Frau und Sport (Frankfurt/M.: Fischer, 1980); Marie-Luise Klein. Frauensport in der Tagespress (Bochum: Studienverl. Brockmeyer, 1986); Birgit Palzkill. Die Entwicklung lesbischer Identität im Sport (Bielefeld: Frauenoffensive, 1990); and Gertrud Pfister. Frauensport in der DDR (Köln: Strauß, 2002). Hungary: Levelekiné, R. Matild, Ed. A Nö és a Sport (Budapest: TTT, 1963). Italy: Giana Maria Madella. Atleta al femminile: la donna e lo sport: storia di un' emancipazione difficile (Como: Editnova, 1979); Alessandro Salvinni. Identita Femminile e Sport (La Nuova Italia, date of publication unknown); Angela Teja. Educazione fisica al femminile (SSS Ed.: Roma 1995), and Gigliola Gori. Female Bodies, Sport, Italian Fascism: Submissive Women and Strong Mothers (London: Frank Cass Publishers, 2004); Norway: Gerd Von der Lippe, ed. Kvinner og Idrett: Fra Myte til Realitet (Oslo, Gyldendal Norsk Forlag, 1982). Spain: Mujer y Deporte (Madrid: Ministerio de Cultura, 1986). United Kingdom: Kathleen E. McCrone. Playing the Game: Sport and the Physical Emancipation of English Women, 1870-1941, (Lexington: University Press of Kentucky, 1988). 
The principal focus of this scholarship reflected the concerns of that which has been termed "Second Wave Feminism", which began in the 1960's and included a critique of the societal roles of women, equality of opportunity in sport, the emancipation of women and their bodies in sport, and obstacles which prohibited the full participation of females in sport. As was the case of feminism in general, the focus broadened to include a range of issues including media representations of the female athlete and sexuality.

\section{The introduction of gender into the discourse in sports studies}

The introduction of "gender" into the discourse in sports studies in the 1970's reflected and depended on the convergence of a number of interrelated factors: the introduction of "gender" into the discourse of the academy by female scholars, especially in women's studies and women's history; the development of disciplines generally and the academic development of sports studies specifically, which included an emphasis placed upon theory (as opposed to practice); second wave feminism and the contemporaneous increase in the participation of women in sport and an increase in the number of female scholars in sports studies; the influence of postmodernism and deconstruction on the development of theory in sports studies (most notably Marxist theory and the work of Italian Antonio Gramsci and French theorists Pierre Bourdieu and Michel Foucault), and, lastly, a general interest in the body in the academy at large.

Following the distinctions made between "sex" 4 and "gender" by Robert J. Stoller (1968) and the influence of an emerging feminist scholarship in which the distinctions between male and female, nature and culture, and sex and gender were being questioned-and dualistic, hierarchical forms of knowledge challenged-scholars in women's studies began to incorporate "gender" in the $1970 \mathrm{~s}^{5}$. According to historian Gisela Boch (1991, p. 7), the concept of "gender" was introduced "... as a social, cultural, political, and historical category, in order to express the insight that women's subordination, inferiority and powerlessness are not dictated by nature, but are social, cultural, political and historical constructions". As another historian, Joan Wallach Scott (1987, p. 153), explains, feminists began to use "gender" as a way of referring to

4 See Boch in Offen, Pierson, R.R., \& Rendell, J. (1991, p. 7) who suggests that the dichotomous distinction between sex and gender is largely specific to the English language. As is the case with the German, Italian, and Turkish languages, there is no term to designate sex and make the distinction between sex and gender in the Danish language. Therefore the term sex, when used in the essay, will be kept in its English form and will be used to designate the biological and gender to be understood as the social and cultural.

5 Refer to the following books that were among the more influential books during this early period: Oakley (1972); Firestone (1970); Chodorow (1968); and Gilligan (1982). the social organization of the relationship between the sexes. Further Scott argues that the word denoted a rejection of the biological determinism implicit in the use of such terms as "sex" or "sexual difference" and that perhaps most importantly, with the use of "gender", feminist scholarship "would fundamentally transform disciplinary paradigms".

As research concerning the development of disciplines reveals, they are dynamic structures that undergo continuous change (King \& Brownell, 1966; Arthur Koestler, 1964). Around the middle of the $20^{\text {th }}$ century, disciplinary boundaries began to blur as methods, approaches, or frameworks known as interdisciplinarity and multidisciplinarity soon began to emerge. At approximately the same time, the discipline of women's studies began to develop. According to Aino Saarinen, feminist researchers were inspired by Thomas S. Kuhn's theories in The Structure of Scientific Revolutions, in which crises in prevailing paradigms were resolved by the emergence of a new research frame (Saarinen, 1992, p. 4). Such a context provided fertile ground for the acceptance of the use of "gender", and its use slowly began to transform disciplines of knowledge. At the same time, rather dramatic changes in the discipline of sports studies began to appear as American scholars called for a transformation of their own discipline (Brooks, 1981; Henry, 1964; Kenyon, 1968; Loy, 1968; Nixon,1967; Rarick, 1967). According to these scholars, it was imperative that sports studies (then known as physical education) become an "academic discipline" (rather than an applied field or pedagogical discipline) and to do so, theoretical work was necessary. In the context of this development, the various sub-disciplines emerged, and the need for more theoretical work opened the way for importing theories from other "parent" disciplines such as history, sociology, etc. Women's issues and the concept of "gender" were then embraced by feminists in a dramatically changing discipline of sports studies.

In the 1960s, "second wave feminism" emerged and brought with it political activism that focused on gaining full social and economic equality in Western nations where women had already gained most legal rights. Second wave feminism produced the context for the emergence of the women's sports movement in North America and Western Europe and produced a steady growth in women's sport at both the national and international levels. While more and more women were entering the sporting arena, feminist analysis of sport "(...) was growing due to the emergence of a small but critical mass of women scholars trained in academic disciplines and excited by the potential of feminist theory", as Susan Birrell notes. By the early 1980s, it was apparent that feminist researchers were engaged in forging connections between feminist theory, sporting institutions, and the social practice of sport or as Ann Hall writes about her own experiences: "As feminists, our theory, politics, and practices are inextricably linked" (Birrell, 1988, p. 477).

Patricia Vertinsky (1999) and Ann Hall (1996) attest to the importance of the convergence of developments in 
feminist thought, postmodern theory, and critical theory in sports studies, particularly with regard to sport history and sport sociology respectively. According to the extensive analysis of Alan Ingham and Peter Donnelly, the simultaneous convergence of three currents of thought - the Gramscian, the poststructuralist, and the Foucauldian became the theoretical tools of sports feminists. The work of Gramsci was useful concerning arguments about patriarchy and enabled a focus on hegemonic masculinity and sport; post-structuralism provided an analysis of the social construction of gender and sexuality and its representation in the media; and Foucault's work concerning power - as hierarchically ordered, possessed by persons, and enmeshed in networks variously asserted through modern institutions and manifested most concretely at the level of the body - informed the discourse and engaged sports feminists (Ingham \& Donnelly, 1990).

Developments concerning the inclusion of "gender" in the discourse were also furthered by an academic interest in the body that became apparent in the 1960s. By the 1970s, there was an expanding interest in the body as a topic of teaching and research as noted by Mike Featherstone and Bryan S. Turner (1993) in the introduction of the first issue of Body and Society. "Bodies are in" noted Arthur W. Frank in a review article in Theory, Culture 85 Society in 1990. Although this interest was a result of a diverse range of theoretical traditions, many scholars attribute it to the influence of the work of French historian and social critic Michel Foucault, the contradictory impulses of modernity, and to feminism (Frank, 1990). Further, given the emphasis upon theory in the discipline of sports studies, as well as the influence of postmodern theories, Foucault, and feminism, a wide-ranging interest in the body was shared by many scholars in sport studies ${ }^{6}$. As Hall writes, the work of Foucault was useful because it regarded the body as an historical and culturally specific entity and allowed the conception of the sexualized body without "positing an original sexual difference or fixed biological essence" (Hall, 1996, p. 53). Foucault's work concerning the social construction of bodies through discourse appealed to sports feminists as they sought to understand the construction of the sporting body through modern sport. With the introduction of the concept of "gender", sports scholars, largely using constructivist theories, came to understand the sporting body as a "gendered" body.

Much of the research that has been done concerning gender and sport has been done in the context of three conceptual or theoretical frameworks that have been used by many feminists, especially sports sociologists and sports historians, in the past twenty-five years. These will be discussed in the following sections in which the focus will be on the assumptions, theories, concepts, and methods used rather than the conclusions that have been drawn

6 A few examples that show the diverse and on-going interest in the body include: Hovden (1983); Greneau (1993); Park (1994); Hall (1994); and Bale and Philo (1997).

\section{The female athlete as subject: disciplinary perspectives}

As Joan Wallach Scott (1987) claims, the first approach to a rewriting of women's history has been based on the assumption that women are indeed different from men and have different experiences than men, which leads to a writing of "her-story" (Howell, 1982). The work of the first female scholars in sports studies similarly noted that the focus of the research had been "on sportsmen and men's sport" (Gerber, Felshin, Berlin, \& Wyrick, 1974) and they then began their research with a focus upon sportswomen and women's sport. What underlay such an approach was the basic assumption that the female athlete was indeed different and her experiences in sport were different as well.

By the 1970s, interest in women and sport was evident in the newly emerging sub-disciplines of sports studies. Following the demand for theoretical work in sports studies, female scholars in the discipline opened the way for a more scholarly approach to the study of women in sport. Some of the most influential work was done by sport philosopher Eleanor Metheny and sport psychologist Dorothy V. Harris. Metheny exposed the ideological, symbolic, and mythic nature of sport, which foreshadowed the feminist critique of sport that would eventually appear $^{7}$. Harris focused on the distinctive nature of the female athlete and incorporated a variety of psychological concepts in the study of female athletes. Harris' work provided the foundation for the beginnings of theoretical work within the sub-discipline of sport psychology with the adaptation of the female apologetic and the notion of psychological androgyny to the sporting context. In particular, the concept of androgyny, in retrospect, can be seen as a transitional concept that would enable the concept of "gender" to be incorporated into sports studies. In 1972, Harris hosted the first conference devoted to women in sport at Pennsylvania State University, in the United States, "Women and Sport: A National Research Conference", and the research presented at this conference revealed an expanding interest concerning the psychological, sociological, physiological, and biomechanical considerations of women in sport.

With the publication of Ellen Gerber, et al. (1974), scholars introduced additional perspectives from history, sociology, and biophysiology to the fledgling literature on the female athlete. This book was of particular significance in that it offered the first feminist perspectives of sport by examining the social construction of woman and femininity, as well as the symbolic aspect of sport, years before ideas concerning social construction of women and sport entered the discourse. At approximately the same time Carole Oglesby's collection of essays, Women and sport: From myth to reality and Hall's previously mentioned monograph also brought a feminist critique to

\footnotetext{
7 Important work before Metheny and Harris was also done. For a discussion of this work see Birrell (1988).
} 
sport research. With this work, "gender" entered the discourse and began to destabilize concepts such as sex and sex roles.

Sports historians from Canada, the United Kingdom and the United States, provided additional feminist critiques of sport and frameworks of an inclusive, relational nature rather than frameworks based on the notion of sexual difference. Nancy Struna called for the inclusion of gender as a "fundamental historical variable" that should lie "at the center of theoretical debates and methodological innovations" in sports history (Struna, 1984, p. 120). Patricia Vertinsky's (1994) work concerning exercise, the physical capabilities of women, and the medical profession further placed gender at the center of historical research and opened the way for research concerning the biological basis of women's exclusion from sport and the social construction of the female body. Jennifer Hargreaves (1994) also forged ideas concerning the social production of gender in and through sport, linking social constructivist theories to the patriarchal character of modern sport.

The historical work of this early period also reflected international perspectives as well as interest in various historical periods, as evidenced by the publication of two collections of papers that were presented at the International Congress on Women and Sport held in Rome, Italy, in 1980. Of vital importance were those devoted to the historical aspects of women and sport, in which scholars from several countries (Australia, Canada, Egypt, England, Germany, Israel, and Japan) explored the participation of women in sport in various historical periods including ancient Greece, the Renaissance, and $19^{\text {th }}$ - and $20^{\text {th }}$ centuries Egypt and Germany. The work of international scholars such as Reet Howell, Max Howell, and Jennifer Hargreaves, as well as American scholar Betty Spears, fostered an interest in women and sport in classical Greece. More recently, classical scholar Bettina Kratzmüller of Austria has continued to refine the scholarship concerning women and sport in classical Greece (Kratzmüller, 2008). In other countries of Continental Europe, Gertrud Pfister's Frau und Sport was published in 1980 and was among the earliest books devoted to women and sport, soon to be followed by Norwegian Gerd von der Lippe's Kvinner og Idrett: Fra Myte til Realitet in 1982 and Leena Liane's Kropp, idrott och kvinnohistoria in 1991 in Finland. The work of these and other European scholars placed the female athlete at the center of the developing work in sports history and lay the foundation for comparative and synoptic work concerning the history of women and sport such as Uriel Simri's A Concise World History of Women's Sports (1983) and Allen Guttmann's Women and Sports: A History (1991), which also appeared in these early years.

A more expansive, international view of the female athlete was also offered by Roberta J. Park (1985), who provided a model for other scholars to follow when examining "gender" more closely from a transatlantic perspective in order to understand how sport is depicted as the "natural" arena of males. Her later work with
J.A. Mangan (1987) indicated a turning point concerning research on women's sports history, as Vertinsky (1994, p. 13) suggests, marking the trend toward the use of feminist analysis of sport and examining the crucial period of the formation of attitudes and practices concerning sport that were predominant in the $20^{\text {th }}$ century.

The research of these and other scholars was of critical importance for it brought the female athlete and her sporting experiences into the discourse and then called for a feminist analyses of sport. Moreover, the questions that this research raised required more complex analyses that would provide further insight concerning the gendered nature of modern sport. Thus 'gender' entered the discourse and began to destabilize concepts such as sex and sex roles.

The assumption of difference, upon which this early research was based, was problematic yet fruitful for future research. On one hand, it presented the notion of sexual difference and reinforced essentialist ideas concerning females, which had prevented their entry into sport and would later be addressed as a political issue concerning equality in sport (English, 1978; Postow, 1980, 1983; Wentz, 1981; Young, 1979). It raised the age-old question about dualistic tending views that both feminism and postmodernism would address. For feminists, engagement with such oppositions as nature versus culture, body versus mind, and private versus public, in which women were identified with the former, was critical in understanding the exclusion of women from sport. As the research of this and later periods revealed, arguments for the exclusion of women and sport were supported by such dominant dualistic views. On the other hand, such reigning assumptions and enduring dualisms evoked important questions that could only be addressed through the incorporation of a revised concept of "gender" into the scholarly discourse. Accompanying this revision was a cultural studies approach, a concern with sociological and historical issues that brought a critique of modern sport and society, and the introduction of postmodern, feminist, and deconstructionist theories.

\section{From the female athlete to cultural critique: Interdisciplinary and relational perspectives}

The study of gender brought an examination of women and men in relation to one another in sport and began to destabilize the discourse, moving it away from a focus on sex and binary modes of thought toward an interdisciplinary focus in the various sub-disciplines ${ }^{8}$. In what Hall (1996) refers to as a turn from "categoric" to "relational" research, feminist research turned away from a focus on the female athlete toward sport and sporting culture and thus introduced a second approach

\footnotetext{
8 Of particular importance here is Costa and Guthrie (1994).
} 
to the study of "gender". Conceiving gender as a process and a relational concept, scholars began to approach research from interdisciplinary and cultural studies perspectives incorporating a number of theories from a variety of disciplines in their analyses. As Scott (1987, p. 41) suggests, gender, when understood in relational terms, requires scholars to ask about the implications of definitions and laws that apply to one group for another group, what do the comparative location and activities of men and women reveal about each other, and what do representations of sexual difference suggest about the structure of social, economic, and political authority. Using the work of Foucault, Gramsci, and postmodern and feminist theories, sports scholars began to deconstruct modern sport, arguing that "sporting practices are historically produced, socially constructed, and culturally defined to serve the interests and needs of powerful groups in society", as Hall (1996, p. 11) later wrote. In a most fertile time of sports studies research, the discipline became much more focused on research and concepts such as globalization, post-colonialism, power, hegemony, masculinity, the socially constructed body, and the media began to dominate the discourse. It was within the subdisciplines of sport sociology and sport history, however, where one finds the use of "gender" as a process most fruitful for research during the 1980s and 1990s.

Feminist scholars in sports, as was the case with postmodernists, began to challenge the anthropocentric definition of knowledge and to critique the epistemology of modernity, specifically its rationalism and dualism as masculine modes of thought that serve to legitimate a patriarchal society ${ }^{9}$. Researchers also began to formulate clear and coherent challenges to the conceptual frameworks in the various sub-disciplines of sport studies. Using new approaches to research, scholars began to recognize the autonomy of sport in society and, therefore, its power of legitimation. The use of analytic cultural criticism, in particular, enabled scholars to examine the ideological processes concerning gender differences in sport, and, as Paul Willis (1982, p. 123) argued, "achievement particularly strengthens male identity; it is assumed that sports success is success at being masculine", and therefore "Physical achievement and masculine activity are taken to be the same". Willis' work further clarified the legitimative power of sport in terms of an ideology of difference and female inferiority and was among the first to portray sport as having been socially constructed and mediated to show that the patriarchal nature of sport is natural.

In addition to analytic cultural criticism, Mary A. Boutilier and Lucinda SanGiovanni (1983) introduced the first analysis of alternative feminist frameworks - liberal feminism, Marxist feminism, radical feminism, and socialist feminism - into the discourse. They questioned the institution of male sports and called for a radical

${ }^{9}$ For a more detailed discussion of the relationship between feminism and postmodernism, see Hekman (1990). transformation of sports, an approach taken by several other scholars. Sport psychologist Dianne Gill noted the importance of a feminist perspective and advocated that research in sport psychology should be placed in a broader cultural context. In 1992, Gill (p. 156) wrote that "sound sport psychological research on gender beliefs and processes within the social context of sport and exercise could advance our overall understanding of gender and sport".

In 1984, Nancy Struna (p. 130) noted the limitations within women's sports history that employed paradigms that had been used to examine men's modern sport. She argued, "[t]he history of sportswomen in the twentieth century also raises innumerable questions about relationships between sport and society and why people became involved in varying degrees in sport". As Vertinsky (1994) notes in her review of women's sports history, Struna advocated the exploration of such themes as conflict, identity, and the relativity of equality. In 1991, Struna focused on both sport and other recreational forms according to consumption and production, which allows sport historians to more fully examine the dimensions of gender relations. Later in 1996, she continued to integrate gender relations into the "broader context of relationships between labor and leisure". In so doing, she framed sport more broadly and thereby more thoughtfully explored the physically recreative and sporting practices of women of the $17^{\text {th }}$ and $18^{\text {th }}$ centuries and revealed the relational nature of gender and sport to the broader historical context. Catriona M. Parratt (1998, p. 9) similarly called for an expanded focus of sport history beyond that of the hierarchical, contemporary understanding of sports as "male, modern, and athletic" to encompass a more diverse range of activities and the writing of women's sports history rather than the history of women in sports.

A focus on power and the processes of domination and subordination, as these relate to gender relations in sport, as well as critiques of the place of sport in cultural productions, brought the body into the discourse (Cole, 1993). Following the early work of Eleanor Metheny concerning the symbolic nature of sport, Jennifer Hargreaves more explicitly linked the symbolic nature of the female body with the patriarchal character of modern sport. The inclusion of the body in the discourse also revealed two additional areas of research that were related to an interest in the body: sexuality and masculinity. In 1981, Ann Hall introduced the idea of sexual identity in sport and this later would be understood as a barrier to the participation of women in sport. The research of Canadian Helen Lenskyj further elaborated the importance of male control of female sexuality and its relationship to the exclusion of women from sport ${ }^{10}$. Lenskyj was among the first to draw attention to the relationships among ideology, female sexuality, and sports participation by linking

\footnotetext{
10 Hall's Hall Sport, sex roles, and sex identity (1981) is perhaps the first text to address issues of sexual identity in the discourse on sport. Lenskyj has continued her work with sport and sexuality in her recent book (2003).
} 
the anatomical, physiological, social, and expressive dimensions of female sexuality ${ }^{11,12}$. Susan K. Cahn's work (1994), which extended the critique beyond that of sport to the American culture at large to show that women's efforts for over a century in sport revealed the history of gender relations in American culture. Equally important is that Cahn's book brought the subject of homophobia and her inclusion (perhaps for the first time) of the question of the De Beauvoirian "other" in women's sport black women and lesbians - into the discourse. Cahn further clarified the notion of sport as contested terrain noting, as few feminist works have, that sport, in addition to being a site of female oppression, is also a site of female liberation (Cahn, 1994) ${ }^{13,14}$.

Feminist critiques concerning sex roles, sexuality, and the patriarchal and sexist character of modern sport also brought a focus on masculinity, and thus male scholars began to critique modern sport as an activity formed as a consequence of a crisis in $19^{\text {th }}$ century masculinity. The early work of D.F. Sabo and R. Runfola in 1980 was followed by critical analyses that used gender as a fundamental category of analysis. Much of this work addressed the nature of the relationship among sport, men, and the gender order and the way in which sport has been used in the construction of masculinity, which is oppressive of women and repressive of men ${ }^{15}$. Slightly later, European scholars also contributed to the research concerning sport and masculinity with different perspectives, often linking sport and masculinity to nationalism and militarism, which differentiated it from research in the United States. Danish scholar Hans Bonde published Mandighed og Sport (Masculinity and Sport) in 1991 and later with his work concerning Niels Bukh, gymnastics and masculinity in Denmark forged a connection between politics, masculinity, and sport. In the United Kingdom, J.A. Mangan initially connected gender and sport with analyses of education of British men in public schools

\footnotetext{
11 Vertinsky (1994) is also an important work in revealing the power of the relationship between discourse, societal views of women, and their participation in sport.

12 The essays in Mangan \& Park's (1987) added to the literature concerning the social construction of femininity and its relation to the exclusion of women from sport. In addition, the book offers the first comparative and transatlantic perspectives concerning women in sport with essays devoted to Great Britain, Commonwealth, and American perspectives.

13 After Birrell and Cole's work introduced homophobia, Pat Griffin published Strong women, deep closets: Lesbians and homophobia in sport (1998).

14 The work of Cahn and others, concerning sexuality has been continued in Scraton and Anne (2002).

15 The earliest work concerning masculinity was done by Donald F. Sabo and Ross Runfola (1980). This pioneering text was followed by several others; among the more influential of which are Messner \& Sabo (1990); Pronger (1990); Messner (1992); Messner \& Sabo (1994); and McKay et al. (2000), which offers perspectives of scholars from Canada, Australia, the United States, and England.
}

and later expanded his analysis to Europe with Making European masculinity: sport, Europe, and gender (2000) and "Manufactured" masculinity: Making imperial manliness, morality and militarism (2012). French scholar Thierry Terret connected rugby to masculinity in Learning to be a man: French rugby and masculinity (1999), and he and Arnaud Waquet - like their European counterparts - linked sport and masculinity to the experience of war and politics (Terret, 2011; Waquet, 2011). Somewhat later, Julie Gaucher, another French scholar, embraced the connections between race, masculinity, sport, and representations of these intersections in French literature, again a different approach to the study of gender and sport (Gaucher, 2009).

The research concerning sexuality also brought discussions of the marginalization of women of color and gay men in sport as well an exploration of homophobia in sport (Connell, 1987). Of considerable note in understanding the relationship between gender and sex and with a focus on the experience of non-elite level athletes - instead of elite level sport - is Brian Pronger's work (1990). Extending the exploration of homosexuality to a broader understanding of the relationship between sex and gender, Pronger's work foreshadowed the work that would begin somewhat later as scholars sought to deconstruct gender in an attempt to understand the relationships among sexuality, sex, and gender, using a new feminist paradigm expressed as intersubjectivity.

Viewing "gender" as a process and with a critique turned toward the contributions of sport and other institutions to the on-going domination and sub-ordination of women, scholars began to critique the institutionalization of discrimination in modern sport. Recognizing sport as an institution that developed, performed, and rewarded discrimination against women was of critical importance in examining other institutions such as the media and politics, which promoted similar ideologies of difference. Of notable importance is the socio-historical analysis of Jennifer Hargreaves (1994) in which she noted the lack of use of gender theories in sport and offered a most comprehensive analysis of the gendered nature of modern sport and the institutionalization of discrimination in modern sport. Scholars became interested as well in the ways in which institutions promoted sexual difference in sport, and researchers soon took up an interest in the media and the "importance of discourses, representations, and ideologies in naturalizing masculine dominance in sporting practices" (McKay \& Huber, 1992, p. 207) ${ }^{16}$.

Research concerning "gender" of the 1980s and 1990s, most particularly in sport history and sport sociology, was important for the academic development of the discipline of sports studies for many reasons. Through a gendered analysis, scholars embraced postmodernism and feminism and brought a much-needed critique of modern sport. The feminist, interdisciplinary, and cultural

\footnotetext{
16 See Creedon (1994) the first book devoted exclusively to women, sport, and the media.
} 
studies approach of this period also challenged the hegemonic nature of knowledge in the discipline (of its theories and paradigms of analysis as well as the relation between the various knowledges and methodologies in the sub-disciplines). Such research "decentered the center", encouraged a movement across the borders of traditional disciplinary configurations, and transformed the methodological approaches as well as the concerns of the discipline. Issues pertaining to "gender" also contributed to the need for an alternative view of gender - the interrelational. Such a view required a new focus for the discipline of sports studies as well and the introduction of new paradigms and methodologies.

It was again the work of Roberta J. Park that reflected changing perspectives and the search for new paradigms and methodologies concerning gender and sport. In 1991, as the guest editor of a special issue of the Journal of the History of Sport that was devoted to gender, Park argues that conceptions of it, "[f]ar from being monolithic . . . may be influenced by race, ethnicity, chronological age, social class, political status and much more". Further, she avers: "For many ... "gender" can best - and probably only - be understood from comparative perspectives". The interconnectedness and interrelational nature of understandings concerning gender and sport had thus become apparent and became the basis for changing views of gender that informed the scholarly discourse in sport as well as requiring different methodological approaches.

\section{Gender as interrational and intersubjective: transdisciplinary perspectives}

In the 1970's women of color, lesbians, and working class feminists began to challenge the feminism of difference that is difference from men - arguing that the perspective was universalizing and a feminism of uniformity. The challenge stemmed from the assumption that all women have something in common and that this commonality creates a particular kind of common experience and, therefore, a uniform understanding of feminism.

A healthy debate that focused on the diversity among women as well as the implications of this diversity for conceptualizations of gender emerged in the literature. The claim was that white middle-class feminists did not speak for all women. According to Spelman, white feminism saw itself as a universal feminism and it did not succeed in reconstructing an inclusive foundation (Spelman, 1988). Second wave feminists had claimed that feminists had used the term "gender" to destabilize biology. As we came to understand, female gender was not simply understood as a cultural and psychological effect of being biologically female, but rather as a cultural effect of male dominance and patriarchy. Women of color insisted that other cultural forces such as racism and classicism were also determinants of female gender, and they determined it differently for white middle-class women, women of color, and poor women.

Feminists responded with an analytical tool known as "intersectionality", which Jennifer C. Nash (2008) recently defined as the feminist paradigm for theorizing identity and oppression and combating hierarchy, hegemony, and exclusivity (within feminism also). Noting that categories - including race and gender - are too simplistic to capture the complexity of lived experience, Nash proposed that gender be understood as the different ways in which women act, think, and feel, given their historical circumstances as well as the variety of roles, expectations, and limitations imposed on them. Moreover, gender always has specific, contextualized meanings; it is not something that all women share in the same way. According to Nash, intersectionality serves a few theoretical and political purposes that enable scholars to create new paradigms for a revisioning of gender. First, it simultaneously subverts binaries concerning race and gender when theorizing identity. Second, racial variations within gender and gendered variations within race can be more easily understood through an intersectional view. Last, intersectionality enables scholars to understand the legacy of exclusions of marginalized subjects from feminist and critical race theories and the impact of those absences on both theory and practice. As critical examinations of society and culture, critical race theory, feminist theory, and Marxist theory, with shared interests in exclusion and privilege in sport, became useful in critiquing sport from an intersectional point of view in the $1970 \mathrm{~s}$ and 1980s.

According to this view, intersectionality is supposed to avoid essentialism precisely because it allows for the recognition of different female genders. It is hoped that it avoids essentialism which posits a sameness about women that can be derived from theories based only on the experiences of middle-class women. Further, intersectionality refers to multiple oppressions experienced by non-white and poor women in particular and requires a de-gendering of our perspectives.

A number of important critiques of gender that pointed toward a need for an intersectional analysis appeared in feminist literature. In her book (2005), Judith Lorber argues that "gender is a binary system of social organization that creates inequality". To degender means "to recognize that the two genders are not at all homogenous categories since they are intersected by other major social statuses - racial ethnic group, social class, national identity, religious affiliation - and by individual variations such as age, sexual orientation, relational and parental statuses, and physical status". In other words, multiplicities of genders - gender diversity and gender freedom - suggest a living outside of the binary sex/gender system. Further Lorber advocates that we should be open to intersexuality, transgender queering, and sexual fluidity and deliberately ambiguous nongendered presentations of self. Further viewing gender 
within the logic of intersectionality redefines it "as a constellation of ideas and social practices that are historically situated within mutually construct multiple systems of oppression" (Collins, 1999).

In support of this new paradigm, third wave feminists, according to Leslie Heywood and Jennifer Drake in Third Wave Agenda, take cultural production and sexual politics as key sites of struggle, seeking to use desire and pleasure, as well as anger, to fuel struggles for justice. Further, third wave feminists seek a new subjectivity and languages and images that account for both multiplicity and difference, that negotiate contradiction in affirmative ways, and that give voice to a politics and coalition.

Questions concerning the methodologies of intersectionality soon appeared in order to conduct research that is not based on universalizing and essentializing ideas research that "lives outside of the binary sex/gender system?" According to Lorber, most research designs (in sociology) assume that each person has one sex, one sexuality, and one gender (Lorber, 1996). In her later work, she argues that we need to recognize the multiplicity of genders, sexes, and sexualities, but the difficulty lies in needing categories for analysis yet at the same time deconstructing them. In other words, how do scholars conduct research without reifying and contributing to the existence of such categories? Further Lorber posits that scholars should split that which has been conflated or joined: sex (biology, physiology); sexuality (desire, sexual preference, sexual orientation); and gender (a social status, sometimes with sexual identity). Additionally scholars argue that there is a need to create research paradigms that examine the social constructions and means of sex, sexuality, and gender as we have done for race, ethnicity, and social class.

This paradigmatic shift toward intersectionality in feminist research also appeared in sports studies research concerned with gender. As early as 1990, sports studies scholars embraced the work of feminist scholars such as Judith Butler, Elizabeth Grosz, and Judith Lorber. As noted previously, following the work of Roberta Park, in the early 1990s, sports historians began to recognize that gender was not monolithic; rather it intersects with a number of other dimensions of human experience and identity in sports such as race, ethnicity, age, social class, and political status. Reflecting a trend toward intersectionality, sports scholars began to approach the study of gender in news ways, including the use of concepts ${ }^{17}$ or themes (rather than theories) and an admixture of methodologies and sources of knowledge, most particularly the use of narratives (Bandy, 2004c; Denison \& Markula, 2003; Markula, 2005; Sparkes \& Silvennionen, 1999). Moreover, scholars began to adopt transdisciplinary and transnational perspectives as they sought to deconstruct gender, viewing gender (and race, social class, and ethnicity) from an interrelational and

\footnotetext{
17 See Bal (2002) for a more detailed examination of the use of concepts in research and teaching.
}

intersectional point of view. Of particular note here is the appearance of a journal explicitly devoted to the use of themes as a means of approaching interdisciplinary perspectives that incorporated ideas that have often been used in scholarly analyses of Sport. Structured around specific topics rather than around specific disciplines, Junctures: The Journal of Thematic Dialogue first appeared in December of 2003 and was created to push the boundaries of interdisciplinarity by including the work of several disciplines from a variety of disciplines, who examine a particular theme such as the body, play, space, language - subjects that can easily be linked to sport.

Scholars have been able to draw from an immense amount of research from a diverse range of perspectives and have adopted new methodologies and approaches to their work, which reflect an approach that "decenters" hierarchical organizations and patterns of knowledge that have predominated and points to the importance of transdisciplinary perspectives ${ }^{18}$. Among the most important of these are the use of concepts ${ }^{19}$ or themes (rather than theories) and an admixture of methodologies and sources of knowledge, most particularly the use of narratives (Sparkes \& Silvennionen, 1999; Denison \& Markula, 2003; Bandy, 2004c; Markula, 2005). In this context, gender becomes fluid and multiple and serves as an interconnecting concept in understanding multiple points of view, resulting in the simultaneous inclusion of a gendered perspective among connecting and multiple perspectives ${ }^{20}$. Although much research that has recently been published fails to incorporate a gender perspective, some research points to transdisciplinary perspectives in sports studies, and a few of these present us with a new and alternative views and treatments of gender and sport ${ }^{21}$.

As scholars continued their work, the interrelational and the multiplicities of gender - intersections between gender, color, ethnicity, race, and sexuality - brought forth an interest in "other" women - women of color,

\footnotetext{
18 See Nicolescu (2002) for an introduction to transdisciplinarity

19 See Bal (2002) for a more detailed examination of the use of concepts in research and teaching.

20 For a discussion of the concept of circularity and a rejection of linearity in language and the hierarchical ordering of knowledge, see Ostriker (1986).

21 It can be argued that Eichberg's "third way", with which he advocated several approaches to the development of a Scandinavian sociology of the body - biographical, autobiographical, situational, scenical, social ecological - suggests new methodological ways of understanding the body, and such an approach foreshadowed the work that would come after the publication of his work in 1994. Similarly Olav Ballisager's work in 2002 concerning "physical culture as idræt and play", shows the interaction between several concepts that produces what Ballisager has identified as a "mutual third". In support of new directions for the integration of gender relations, physical education, and sport history, Patricia Vertinsky advocates, like Eichberg, the importance of comparative studies using intercultural and inter-lingual perspectives.
} 
lesbians and those outside the margins of mainstream sport theory and practice - entered the discourse, most notably in the sociological approach to sport. Susan Cahn's work concerning the "Cinderellas" of sport, for example, included histories of women of color as well as lesbians in sport. Jennifer Hargreaves (2000) similarly recognized the "others" in sport in a study of Aboriginal, disabled, Muslim, and lesbian women from a transnational perspective $^{22}$. Rather than in interest in the globalizing process and its impact upon contemporary sport, Hargreaves looks from a transnational point of view and uses an admixture of methods and sources to examine the relationship between sporting experiences and identity of "others" from different parts of the world. Using Foucault's notions of power, she examines power relations among women, using concepts of inclusion and exclusion, power and privilege, and the relationship between the local and the global. In this context, gender is seen as a shared and universal experience, while at the same time is an experience of difference (according to nationality, sexuality, physical ability, religion, and social class) and individual identity in sport. With an interest in the transnational - as that which exists between nations or perhaps between people - Hargreaves' work examines both the simultaneity of multiple oppressions and the complexity of identity.

In an attempt to further deconstruct gender within the context of sport, intersectionality surfaced as a methodology or approach to understanding the multiplicity and fluidity of gender. For example, Leslie Heywood and Shari L. Dworkin (2003) study the female athlete as a cultural icon through a variety of approaches: feminist theory, film, interviews, poetry, and representation. Their work also focuses on the body in sport, including the female and male body in sport, attempting to further explore the fluidity of gender. In a similar way, Barbara Cos and Shona Thompson connect "multiple bodies" in sport with matters concerning the experiences of sexuality in sport and the multiple discourses that suggest the liberating bodily experiences of female soccer (football) players (Cos \& Thompson, 2000).

Historians also turned to less traditional sources in writing scholarly analyses of sports history with the intention of more fully examining their subject. According to Jeff Segrave's analysis, Elliot Gorn's book, The Manly Art, is not just the history of the sport itself. Rather it includes gender history, social history, and labor history in an analysis of boxing. In this integrative approach, Gorn uses sources that are often not used in more traditional sport history: newspapers and popular pamphlets, fiction and poetry, and even doggerel verse and ballads (Segrave, 2010).

It can be argued that Löic Wacquant, former student of Pierre Bourdieu with whom he wrote An Invitation

\footnotetext{
22 Hargreaves used archival materials, newspapers and magazines, personal correspondence, films and videos, material from the internet, and interviews using the internet.
}

to Reflexive Sociology (1992), more consciously mixes sources, theories, and methodologies, while embracing intersectionality as a method of studying sport by viewing race, gender, and sport, as social processes that inform each other while at the same time operate in specific ways. In analyzing race in Body and Soul: Notes of An Apprentice Boxer (2004), for example, Wacquant advocated that social scientists should "skirt the issues of origins and abandon a search for a single overarching concept to develop an analysis of racial domination". In his work, he dismisses a search for "origins" and examines the way various processes of subordination and experience coalesce during particular social moments. In his masterful analysis of boxing, Wacquant not only embraces intersectionality, he utilizes a transdisciplinary approach, including the perspectives of sociology, ethnology, literature, and sport to provide a social critique from the perspectives of the nexus of race, social class, and gender. Educated as a sociologist and engaged as an amateur boxer, Wacquant brings to his analysis sociological theory, ethnographic "data", and literary insights while at the same time validating experiential, gendered, and bodily ways of knowing from the sport experience. Such an examination reveals knowledge that exists on different levels of reality and is revealed in multiple ways of knowing, thus pointing to the importance of transdisciplinary approaches to the study of sport. Wacquant describes the purpose of his book as follows.

"Breaking with the moralizing discourse - that indifferently feeds on celebration and denigrations produced by the "gaze from afar" of an outside observer standing at a distance from or above the specific universe, this book seeks to suggest how boxing "makes sense" as soon as one takes pains to get close enough to it to grasp it with one's $b o d y$, in a quasi-experimental situation. It is for this reason composed of three texts of deliberately disparate statuses and styles, which juxtapose sociological analysis, ethnographic description, and literary evocations in order to convey at once percept and concept, the hidden determinations and the lived experiences, the external factors and the internal sensations that intermingle to make the boxer's world. In short, the book aims to display and demonstrate in the same move the social and sensual logic that informs boxing as a bodily craft in the contemporary black American ghetto (Wacquant, 2004, p. 7)."

Scholars of sport can draw from Wacquant's work in a number of important ways: examining the way in which racial and social categories utilize differing technologies of categorization, observing the disciplining of the body in distinctive ways, and reflecting upon the coalescence of certain social, historical, representational, bodily, and sporting experiences.

The introduction of "queer theory" also supplied a theoretical framework that could be used to advance 
intersectional and transdisciplinary investigations of gender and sport. Introduced in 1991 by Teresa de Laurentis, "queer theory" provoked a critique of sexual identity and postmodernism's suspicion of fundamental truths an categories and altered the way we think about gender, sexuality, desire, and the body in sports studies. On a theoretical level, scholars have noted the absence of queer theory in sport - as is the case of the academy in general revealing that this absence has worked against a more expansive, comprehensive, interrelational, and intersectional analysis of sport. As queer theorists have discovered, multiple categories disturb the comfortable polity of the familiar opposites that assume one dominant and one subordinate group, one normal and one deviant identity, one hegemonic status and one "other".

The most recent theoretical development in sports studies has been a focus on sexuality from an intersectional point of view. Influenced by expanding notions of gender and this influence of queer theory, researchers have recently focused on the control and containment of female sexuality and the expression of sexuality in women's sports, turning their attention to sex testing and gender verification by sports organizations and to transsexual and transgender policies in sport (Caudwell 2006; Cavanaugh \& Sykes, 2006; Ritchie, 2003; Sykes, 2006).

\section{Bibliography}

Bal, M. (2002). Traveling concepts in the humanities: A rough guide. London: University of Toronto Press.

Bale, J., \& Philo, C. (Eds.) (1997). Body cultures: Essays on sport, space and identity. London: Routledge.

Bandy, S.J. (2004a). Fra "sex" til "gender", fra kvinder og sport til kulturkritik og fradet nationale til det transnationale: En oversight over amerikansk, canadisk og britisk forskning I sport og køn, Dansk Sociologi, Nr. 2/15, Juli, 125-135.

Bandy, S.J. (Ed.) (2004b). Nordic narratives in sport and physical culture: Transdisciplinary perspectives, Skriftserien LUDUS, nr. 2, Faculty of Natural Sciences, Århus Universitet, 17-39.

Bandy, S.J. (2004c). Transdisciplinarity, sport, and physical culture: An Introduction. In S.J. Bandy (Ed.), Nordic narratives in sport and physical culture: Transdisciplinary perspectives (pp. 17-39). Skriftserien LUDUS, nr. 2, 2004, Faculty of Natural Sciences, Århus Universitet.

Birrell, S. (1988). Discourses on the gender/sport relationship: From women in sport to gender relations. Exercise and Sport Sciences Reviews, 16, 459-502.

Boch G. (1991). Challenging dichotomies: Perspectives on women's history. In K. Offen, et al., (Eds). Writing women's history: International perspectives (pp. 1-23). London: Macmillan.

Bonde, H. (1991). Mandighed og Sport. Odense: Universitetsforlag.

Bourdieu P., \& Wacquant, L. (1992). An invitation to reflexive sociology. Chicago: University of Chicago Press.
Boutilier, M.A., \& SanGiovanni, L. (1983). The sporting woman. Champaign, IL: Human Kinetics Publishers.

Brooks, G.A. (Ed.) (1981). Perspectives on the academic discipline of physical education Champaign, IL: Human Kinetics Publishers.

Cahn, S.K. (1994). Coming on strong: Gender and sexuality in twentieth century women's sport. London: Harvard University Press.

Caudwell, J. (2006). Sport, sexualities and queer theory. London: Routledge.

Cavanaugh, S., \& Sykes, H. (2006). Transsexual bodies at the Olympics: The international olympic policy on transsexual athletes at the Athens summer games. Body and Society, $12,(3), 75-102$.

Chodorow, N. (1978). The reproduction of mothering: Psychoanalysis and the sociology of gender. Berkeley: University of California Press.

Cole, C.L. (1993). Resisting the Canon: Feminist Cultural Studies, Sport, and Technologies of the Body. Journal of Sport and Social Issues, 17, 79-97.

Collins, P.H. (1999). Moving beyond gender: Intersectionality and scientific knowledge. In Myra Marx Ferree, et al. (Eds.), Revisioning gender. Thousand Oaks, CA: Sage Publications.

Connell, R.W. (1987). Gender and power: Society, the person, and sexual politics. Stanford, CA: Stanford University Press.

Cos, B., \& Thompson, S. (2000). Multiple bodies: Sportswomen, soccer and sex. International Review of Sociology of Sport, 35, 5-20.

Costa, D.M., \&. Guthrie, S.R. (Eds.) (1994). Women and sport: Interdisciplinary perspectives. Champaign, IL: Human Kinetics.

Creedon, P.J. (Ed.) (1994). Women, media and sport: Challenging gender values. London: Sage Publications.

Denison, J., \& Markula, P. (Eds.) (2003). Moving writing: Crafting movement in sport research. New York: Peter Lang.

English, J. (1978). Sex equality in sport. Philosophy and Public Affairs, 7 (3), 269-277.

Featherstone, M., \& Turner, B.S. (1993). Body and society: An introduction. Body and Society, I (1), 1-12.

Firestone, S. (1970). The dialectic of sex. New York: Bantam Books.

Flintoff, A., \& Scraton, S. (Eds.). (2002) Gender, Sport and Sexuality. London: Routledge.

Frank, A.W. (1990). Bringing bodies back in: A decade review. Theory, Culture 85 Society, 7, 131-162.

Gaucher, J. (2009). Black males in the stadium: All "bad niggers"? French literature, sport and masculinity from the 1920 s to the 1950s. The International Journal of the History of Sport, 26 (9), 1171-1186.

Gerber, E., Felshin, J., Berlin, P., \& Wyrick W. (Eds.) (1974). The American woman in sport. London: Addison- Wesley Publishing Company.

Gill, D. (1992). Gender and Sport Behavior. In T.S. Horn (Ed.). Advances in sport psychology (pp. 355-275). Champaign, IL: Human Kinetics. 
Gilligan, C. (1982). In a different voice: Psychological theory and women's development. Cambridge, MA: Harvard University Press.

Gorn, E.J. (1986). The manly art: Bare-Knuckle prize fighting in America. Ithaca: Cornell University.

Greneau, R. (1993). The critique of sport in modernity: Power, culture, and the politics of the body. In E, A. Dunning, et al. (Eds.), The sports process: A comparative and developmental approach (pp. 85-109). London: Human Kinetics.

Griffin, P. (1998). Strong Women, Deep Closets: Lesbians and Homophobia in Sport. Champaign, IL: Human Kinetics.

Hall, M.A. (1978). Sport and gender: A feminist perspective on the sociology of sport. Ottawa: CAHPER.

Hall, M.A. (1981). Sport, sex roles, and sex identity. Ottawa, Ontario: Canadian Research Institute for the Advancement of Women.

Hall, M.A. (1988). The discourse of gender and sport: From femininity to feminism. Sociology of Sport Journal, 5, $330-340$.

Hall, M.A. (1996). Feminism and sporting bodies: Essays on theory and practice. Champaign, IL: Human Kinetics.

Hargreaves, J. (1994). Sporting females: Critical issues in the history and sociology of women's sports. London: Routledge.

Hargreaves, J. (2000). Heroines of sport: The politics of difference and identity. New York: Routledge.

Hartmann-Tews, I., \& Pfister, G. (Eds.) (2003). Sport and women: Social issues in international perspective. London: Routledge and ISCPES.

Hekman, S.J. (1990). Gender and knowledge: Elements of a postmodern feminism. Cambridge: Polity Press.

Henry, F. (1964). Physical education: An academic discipline. Journal of Health, Physical Education, and Recreation, 35, 32-33, 69.

Heywood, L., \& Dworkin, S.L. (2003) Built to win: The female athlete as cultural icon. Minneapolis: University of Minnesota Press.

Hovden, J. (1983). The female top athlete's body as a symbol of modern femininity. In L. Laine (Ed.), On the fringes of sport (pp. 84-91). Sankt Augustin, Germany: Academia Verlag.

Howell, R. (Ed.) (1982). Her story in sport: A historical anthology of women in aports. West Point, NY: Leisure Press.

Ingham, A.G., \& Donnelly, P. (1997) A sociology of North American sociology of sport: Disunity in unity, 1965 to 1996. Sociology of Sport Journal, 14, 363-418.

Kenyon, G.S. (1968). On the conceptualization of subdisciplines within an academic discipline dealing with human movement. Proceedings of the NCPEAM National Conference, 34-45.

King, A.R., \& Brownell, J.A. (1966). The curriculum and the disciplines of knowledge. New York: John Wiley and Sons, Inc.

Koestler, A. (1964). The act of creation. New York: Macmillan.
Kratzmüller, B. (2008). Girls running a race in the ancient gymnasion of Bauron? - Ancient arkteia and Bauronia reconsidered. In G. Gori (Ed.), Sport and gender matters in western countries: Old borders and new challenge (pp. 15-31). Sankt Augustin: Academia Verlag.

Lenskyj, H.J. (2003). Out on the field: Gender, sport, and sexualities. Toronto, ON: Women's Press.

Lorber, J. (1996). Beyond binaries: Depolarizing the categories of sex, sexuality, and gender. Sociological Inquiry, 66 (2), 143-159.

Lorber, J. (2005). Breaking the bowls: Degendering and feminist change. New York: W.W. Norton \& Company.

Loy, J. (1968). The nature of sport: A definitional effort. Quest, 10, 1-15.

Mangan, J.A., \& Park, R.J. (1987). From "fair sex" to feminism: Sport and the socialization of women in the industrial and post-industrial eras. London: Frank Cass and Company Ltd.

Mangan, J.A. (2000). Making European masculinity: Sport, Europe, and gender. London: Routledge.

Mangan, J.A. (2012). Manufactured masculinity: Making imperial manliness, morality and militarism. London: Routledge.

Markula, P. (Ed.) (2005). Feminist sport studies: Sharing experiences of joy and pain. Albany, NY: State University of New York Press.

McKay, J., \& Huber, D. (1992). Anchoring media images of technology and sport. Women's Studies International Forum, 15 (2), 205-218.

McKay, J., Messner, M., \& Sabo, D. (Eds.) (2000). Masculinities, gender relations, and sport. Thousand Oaks, CA: Sage Publications.

Messner, M.A. (1992). Power at play: Sports and the problem of masculinity. Boston: Beacon Press.

Messner, M.A, \& Sabo, D. (1990). Sport, men, and the gender order: Critical feminist perspectives. Champaign, IL: Human Kinetics.

Messner, M.A., \& Sabo, D.F. (1994). Sex, violence and power in sports: Rethinking masculinity. Freedom, CA: Crossing Press.

Nash, J.C. (2008). Re-thinking intersectionality. Feminist Review, 89, 1-15.

Nicolescu, B. (2002). Manifesto of transdisciplinarity. Trans. By Karen-Claire Voss. Albany, NY: State University of New York Press.

Nixon, J.E. (1967). The criteria of a discipline. Quest, IX, $42-48$.

Oakley, A. (1972). Sex, gender and society. London: Temple Smith.

Offen, K., Pierson, R.R., \& Rendell, J. (Eds.) (1991). Writing women's history: International perspectives. London: Macmillan.

Oglesby, C.A. (Ed.) (1978). Women and sport: From myth to reality. Philadelphia: Lea \& Febiger.

Ostriker, A.S. (1986). Stealing the language: The emergence of women's poetry in America. Boston: Beacon Press. 
Park, R.J. (1985). Sport, gender and society in a transatlantic Victorian perspective. British Journal of Sports History, 2, 5-28.

Park, R.J. (1991). Guest editor's introduction. Journal of Sport History, 18 (1), 5-9.

Park, R.J. (1994). A decade of the body: Researching and writing about the history of Health fitness, exercise and sport, 1983-1993. Journal of Sport History, 21, (1) 59-82.

Parratt, C.M. (1994). From the history of women in sport to women's sport history. In Costa. D.M., \& Guthrie, S.R. (Eds.). Women and sport: Interdisciplinary perspectives (pp. 5-14). Champaign, IL: Human Kinetics.

Parratt, C.M. (1998). Little means or time: Working-class women and leisure in late Victorian and Edwardian England. The International Journal of the History of Sport, 15 (2), 22-53.

Pfister, G. (2000). Doing gender - die Inszenierung des Geschlechts im Eiskunstlauf und im Kunstturnen. In Norberg, J.R. (Hrsg.), Studier $i$ idrott, historia och samhälle. Tillägnade professor Jan Lindroth pa has 60-arsdag (pp. 170-201). Stockholm: HLA Förlag.

Postow, B.C. (1980). Women and masculine sports. Journal of the Philosophy of Sport, VII, 51-58.

Postow, B.C. (Ed.) (1983). Women, philosophy, and sport: A collection of new essays. Metuchen, NJ: Scarecrow Press.

Pronger, B. (1990). The arena of masculinity: Sports, homosexuality, and the meaning of sex. New York: St. Martin's Press.

Rarick, G.L. (1967). The domain of physical education as a discipline. Quest, IX, 49-52.

Ritchie, I. (2003). Sex tested, gender verified: Controlling female sexuality in the age of containment. Sport History Review, 34, 80-98.

Saarinen A. (1992). Feminist research - intellectual adventure? Tampere: University of Tampere Research Institute for Social Sciences.

Sabo, D.F., \& Runfola, R. (1980). Jock: sports and male identity. Englewood Cliffs, NJ: Prentice-Hall.

Scott, J.W. (1987). Women's history and the rewriting of history. In Farnham, C. (Ed.). The impact of feminist research in the academy (pp. 34-50). Bloomington, IN: Indiana University Press.

Scraton, S., \& Flintoff, A. (Eds.) (2002). Gender and sport, London: Routledge.

Segrave, J.O. (2010). Perspectives on the development of sport literature and narrativity: From modernism to postmodernism. In V. Bjerre, \& S.J. Bandy (Eds.), Fortcllinger om idrct i norden: Helte, erindringer og identitet (pp. 29-46). Aarhus: Aarhus University Press.

Sparkes, A.C., \& Silvennoinen, M. (Eds.) (1999). Talking bodies. Jyväskylä, Finland: University of Jyväskylä.
Spelman, E. (1988). Inessential woman. Boston: Beacon Press.

Stoller, R.J. (1968) Sex and gender: The development of masculinity and femininity. London: Karnac Books.

Struna, N. (1984). Beyond Mapping Experience: The Need for Understanding the History of American Sporting Women. Journal of Sport History, 11, 120-11.

Struna, N. (1991). Gender and sporting practice in early America, 1750-1810. Journal of Sport History, 18 (1), 1030

Struna, N. (1996). People of prowess: Sport, leisure, and labor in early Anglo- America, Urbana: University of Illinois Press.

Sykes, H. (2006) Transsexual and transgender policies in sport. Women in Sport and Physical Activity Journal, 15 (1), 3-13.

Terret, T. (1999). Learning to be a man: French rugby and masculinity. In Chandler, T., \& Nauright J. (Eds.), Making the rugby world: Race, gender, commerce (pp. 88-101). Portland, OR: Frank Cass.

Terret, T. (2011). Prologue: Making men, destroying bodies: Sport, masculinity, and the Great War experience. The International Journal of the History of Sport, 28 (3-4), 323-328.

Trangbæk, E., \& Krüger, A. (Eds.) (1999). Gender \&s sport from European perspectives. Copenhagen: Institute of Exercise and Sport Sciences.

Vertinsky, P.A. (1994). Gender relations, women's history and sport history: A decade of changing enquiry, 1983-1993. Journal of Sport History, 21 (1), 1-24.

Vertinsky, P.A. (1994). The eternally wounded woman: Women, doctors, and exercise in the late nineteenth century. Chicago: University Press.

Vertinsky, P.A. (1999). Gender relations, physical education and sport history: Is it time for a collaborative research agenda? In E. Trangbæk, \& A. Krüger, (Eds.), Gender \& sport from European perspectives (pp. 1-27). Copenhagen: Institute of Exercise and Sport Sciences, University of Copenhagen.

Wacquant, L. (2004). Body and soul: Notebooks of an apprentice boxer. Oxford: Oxford University.

Waquet, A. (2011). Sport in the trenches: The new deal for masculinity in France. The International Journal of the History of Sport, 28, (3-4), 331-350.

Wentz, P. (1981). Human equality in sports. The Philosophical Forum, XII (3), 238-250.

Willis, P. (1982). Women in sport and ideology. In J. Hargreaves (Ed.) Sport, culture and ideology (pp. 117-135). London: Routledge and Kegan Paul.

Young, I.M. (1979). The exclusion of women from sport: Conceptual and existential dimensions. Philosophy in Context, 9, 44-53. 